\title{
Intrauterine lower extremity gangrene in a newborn with Tetralogy of Fallot
}

\author{
Ali Seker, Mahmut Enes Kayaalp, Melih Malkoc, Adnan Kara
}

Department of Orthopaedics and Traumatology, Istanbul Medipol University, School of Medicine, Istanbul, Turkey

\section{Correspondence to} Dr Mahmut Enes Kayaalp, mek@mek.md

Accepted 27 February 2016

\section{DESCRIPTION}

Intrauterine gangrene of an extremity is a rare problem. Lower extremity gangrene is even rarer. ${ }^{1}$ We present a case of lower extremity gangrene in combination with Tetralogy of Fallot (TOF) and postaxial polydactyly of the hand. A live male infant was delivered by caesarean section. Delivery occurred at the 34th week of gestation due to meconium aspiration and intrauterine growth retardation. The mother was 35 years of age and had three healthy children. She had been diagnosed with gestational hypertension during this pregnancy. The newborn patient weighed $1740 \mathrm{~g}$ (10th centile) and his length was $43 \mathrm{~cm}$ (25th centile). After birth, he developed respiratory distress and was intubated. Examination revealed postaxial polydactyly with palpable phalanxes on the left hand, with an attached necrotic soft tissue mass (figure 1), as well as lower extremity gangrene with a visible demarcation line on the left middle thigh (figures 2 and 3 ).

Blood test results were normal except for a low platelet count of $73000 / \mathrm{mm}^{3}$ (normal range $130000-510000 / \mathrm{mm}^{3}$ ), elevated D-dimer of $1154.88 \mathrm{ng} / \mathrm{mL}$ (normal range $<500 \mathrm{ng} / \mathrm{mL}$ ), low antithrombin III activity of 55\% (normal range 70$125 \%$ ) and low protein-S activity of $22 \%$ (normal range $33-93 \%)$.

Doppler ultrasonography revealed blocked arterial flow below the level of the tibioperoneal trunk. The main, deep and superficial femoral and popliteal arteries were patent. The patient also had TOF, which was diagnosed by a cardiologist. A transfemoral amputation and polydactyly excision were performed on the third day after birth. The histopathological investigation of the tissue blocks from the amputation material was not helpful in identifying the aetiology. On the 32 nd day after birth, the

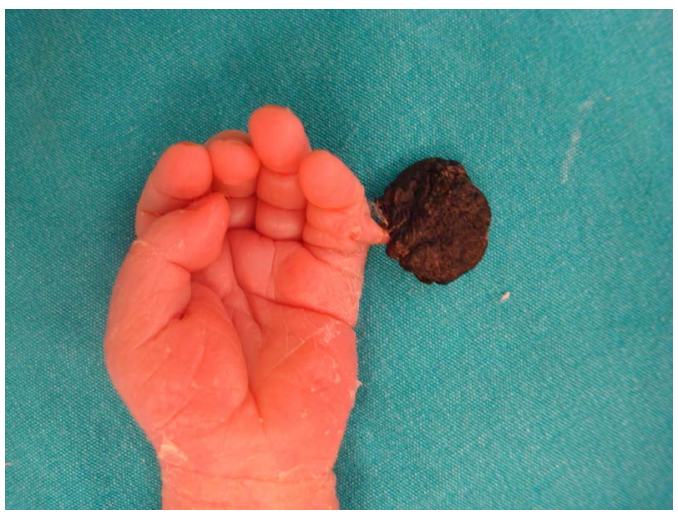

Figure 1 Postaxial polydactyly with an attached necrotic soft tissue mass.

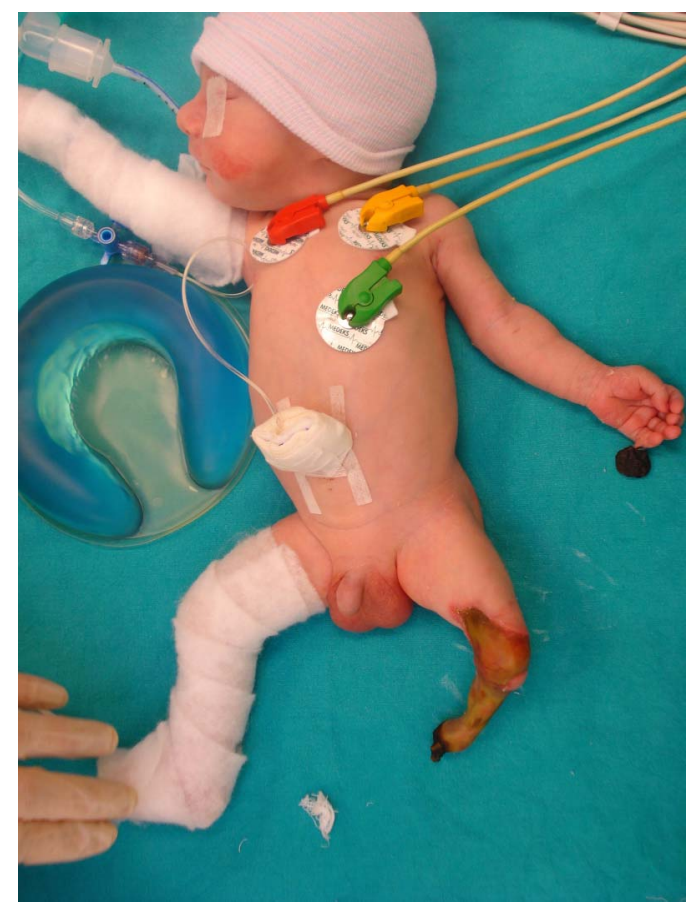

Figure 2 Infant with Tetralogy of Fallot, intrauterine lower extremity gangrene and postaxial polydactyly.

patient was operated for TOF. He died on the seventh postoperative day due to cardiac arrest.

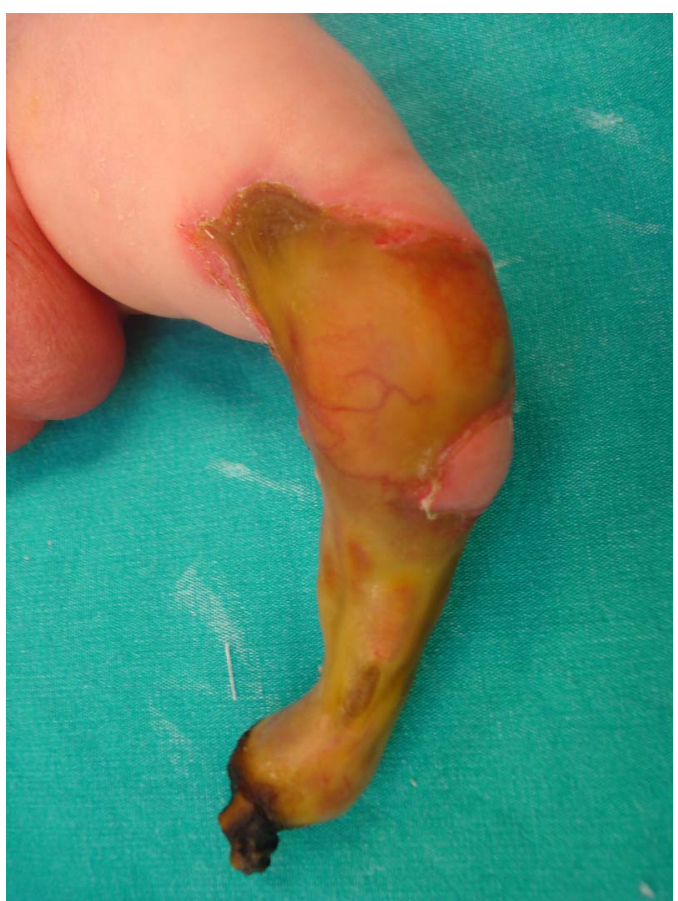

Figure 3 Visible transfemoral demarcation line. 
Various prenatal and perinatal factors can contribute to intrauterine gangrene, including compression or ischaemia. Compression can be caused by uterine anomalies, abnormal fetal presentation, and oligohydramnios or amniotic bands, while ischaemia can result from thrombosis or embolism.

Maternal diabetes, pregnancy-induced hypertension, preterm delivery, dehydration, polycythaemia, congenital heart disease, placental emboli, coagulation abnormalities and twin-to-twin transfusion syndrome may also be underlying causes. The patient had a low platelet count, but his antithrombin III and protein $\mathrm{S}$ activity were also decreased, which can be low in neonates and may cause a transient thrombophilic period. The addition of anomalies or other predisposing factors, such as those listed above, would increase the risk of thrombus formation despite a low platelet count.

In this case, another recognisable predisposing factor was gestational hypertension, which may cause ischaemia. ${ }^{2}$ Although TOF is an accepted risk factor for upper extremity ischaemia and upper extremity anomalies, ${ }^{3}$ there is no such report related to lower extremity ischaemia.

The treatment of intrauterine gangrene consists of maintaining homoeostasis and preventing infection, followed by amputation in the presence of a visible demarcation line.

\section{Learning points}

Intrauterine ischaemia is a rare entity that may lead to devastating consequences such as amputation.

- Gestational hypertension is an important predisposing factor for intrauterine gangrene.

Contributors AS operated on the patient and wrote the manuscript with MEK. MM took the photographs. AK checked the final manuscript.

Competing interests None declared.

\section{Patient consent Obtained.}

Provenance and peer review Not commissioned; externally peer reviewed.

\section{REFERENCES}

1 Tanvig M, Jørgensen JS, Nybo M, et al. Intrauterine extremity gangrene and cerebral infarction at term: a case report. Case Rep Pediatr 2011;2011:363517.

2 Turnpenny PD, Stahl S, Bowers D, et al. Peripheral ischaemia and gangrene presenting at birth. Eur J Pediatr 1992;151:550-4.

3 Carnero Alcázar M, Marianeschi S, Ruiz Alonso E, et al. Left arm underdevelopment secondary to an isolated left subclavian artery in tetralogy of Fallot. Ann Thorac Surg 2010;89:637-9.

Copyright 2016 BMJ Publishing Group. All rights reserved. For permission to reuse any of this content visit http://group.bmj.com/group/rights-licensing/permissions.

BMJ Case Report Fellows may re-use this article for personal use and teaching without any further permission.

Become a Fellow of BMJ Case Reports today and you can:

- Submit as many cases as you like

- Enjoy fast sympathetic peer review and rapid publication of accepted articles

- Access all the published articles

- Re-use any of the published material for personal use and teaching without further permission

For information on Institutional Fellowships contact consortiasales@bmjgroup.com

Visit casereports.bmj.com for more articles like this and to become a Fellow 